\title{
A Man and the Biosphere Reserve as a natural and socio-economic laboratory for the sustainable future of small rural communities
}

\section{Sara Di Lonardo \& Andrea Cinocca}

Keywords: Collemeluccio-Montedimezzo-Alto Molise, UNESCO, MAB Programme, management

\section{Abstract}

The UNESCO Man and the Biosphere Reserve Collemeluccio-Montedimezzo-Alto Molise was established in 1977 in Molise Region (Central Italy) to safeguard local natural and managed ecosystems in two separate areas administered by two different municipalities. An association of seven small municipalities with various local bodies, the ASSOMAB Alto Molise Consortium, was established in 2006 to expand and zone the Reserve in order to promote innovative and environmentally sustainable approaches to economic and social development, by setting in place a new model of sustainable and integrated management in the area. In the renewal step of 2014, UNESCO agreed the expansion of the old protected areas into a single, larger reserve, to be managed by the Consortium. Today it covers nine Natura 2000 sites, seven of which are included in the European Habitats Directive, and two in the Birds Directive. Local administrators and stakeholders see the Reserve as an opportunity to develop sustainable actions while protecting and enhancing the extraordinary environmental richness, including the remarkable biodiversity. In this paper, the authors discuss the current situation and the socio-economic opportunities in this rural landscape, which is affected by population ageing, outmigration and a diminishing economy, all of which are significant drivers of land-use changes, particularly land abandonment and forest expansion.

\section{Profile}

Protected area

Collemeluccio-Mon-

tedimezzo-Alto Molise

Biosphere Reserve

Mountain range

Central Apennines

Country

Italy

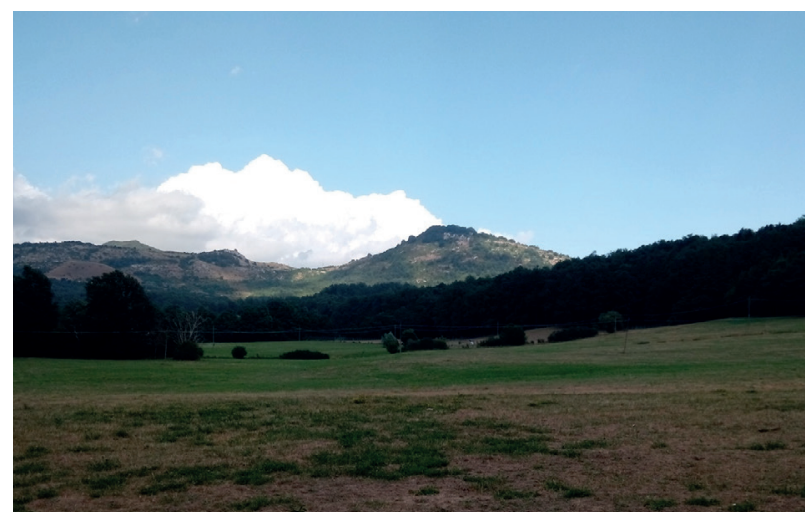

Figure 1 - Part of the Collemeluccio-Montedimezzo Alto Molise Biosphere Reserve. (C) Sara Di Lonardo

\section{Introduction}

In 1977, UNESCO established Italy's first Man and the Biosphere (MAB) Reserve, the CollemeluccioMontedimezzo Alto Molise Biosphere Reserve (BR). It was located in the Central Apennines (in Molise Region; Figure $1 \& 2$ ) and initially comprised 637 ha, covering two separate, uninhabited, nuclei of woods.

In order to implement the enlargement and the zoning of the area, the Area di Sviluppo SOstenibile - (ASSO) MAB Alto Molise Consortium was established in Autumn 2006.

To date, the members of the Consortium are the small villages of Carovilli, Chiauci, Pescolanciano,
Pietrabbondante, Roccasicura, San Pietro Avellana and Vastogirardi, the University of Molise, the Territorial Office for Biodiversity of the National Forest Service, and the Molise Region. The members of the Consortium shared the priority objectives of submitting a review of the BR and its strategies, with a view to updating them, and of putting into practice a new model of sustainable management. The new model (or models) was to take into account the variety of ecosystems found in the biogeographic region and the various human activities taking place at local level. Hence, in June 2014, after the periodic review, the BR was expanded to 25268 ha, which includes the territories of seven neighboring municipalities; the interesting landscape heritage of the whole area is now under the care of the expanded BR. The enlargement of the BR, following a voluntary process, brought into being the first homogeneous area of sustainable development in Molise Region, enhancing both the area's environmental characteristics and its socio-economic activities.

Biodiversity and its conservation as a driver for educational involvement and for restarting the economy

The elevation in the BR ranges from 450 to $1730 \mathrm{~m}$ a.s.l. (Figure 2). The BR covers nine Natura 2000 sites (33\% of the whole Reserve); seven of these are covered by the European Habitats Directive (European Council Directive 92/43/EEC) and two by the Birds 


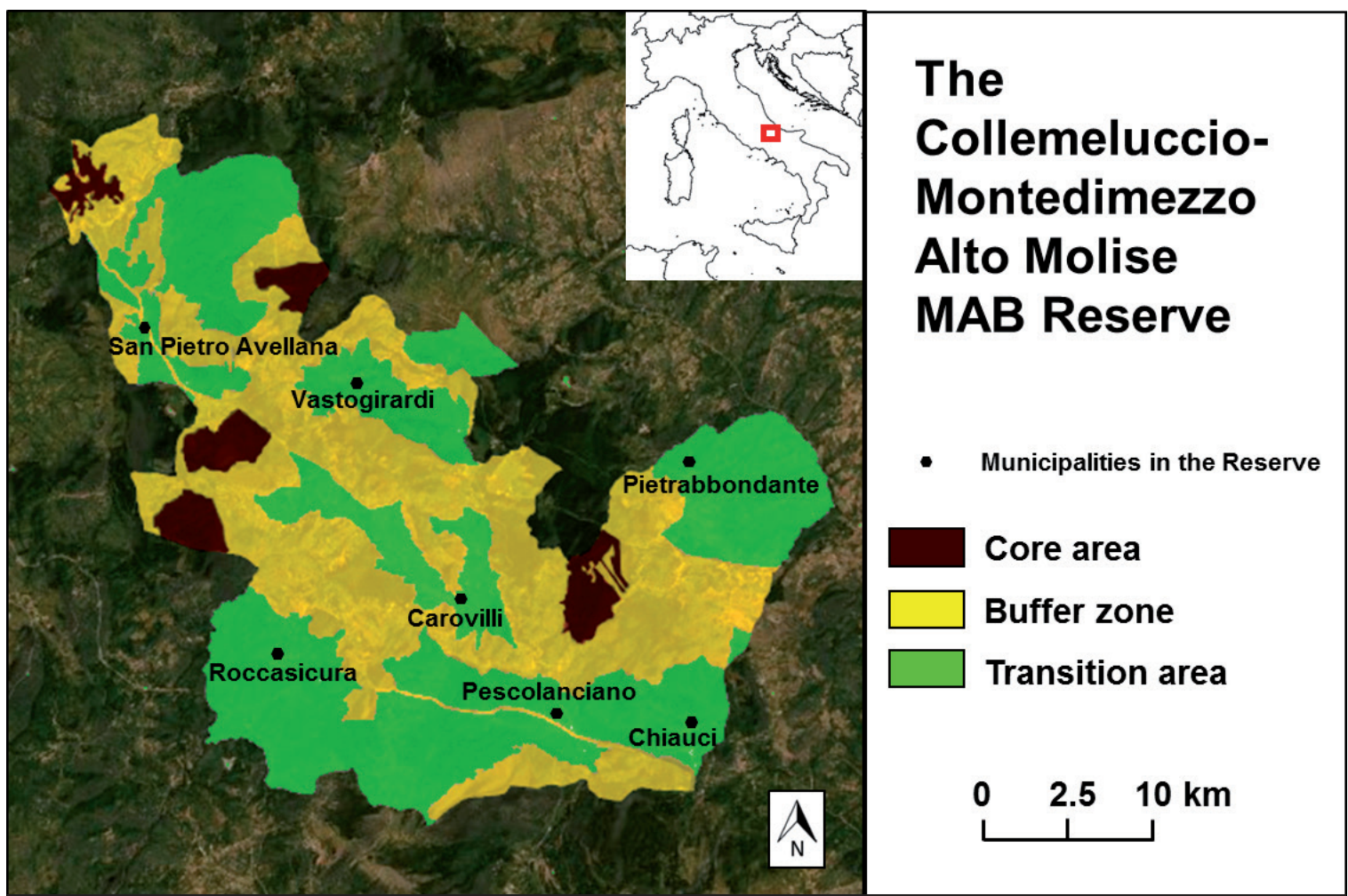

Figure 2 - The Collemeluccio-Montedimezzo Alto Molise Biosphere Reserve today (C) Sara Di Lonardo

Directive (European Council Directive 2009/147/ EEC) (Table 1).

A survey carried out in 2012-2013 updated the checklist of the animal species of interest in the BR (Abbate \& Giovi 2002) to include 48 species of mammals, 112 species of birds, 10 species of amphibians, 8 species of reptiles, 5 fish species and 9 invertebrate species included in the EU Habitats Directive. Where flora is concerned, there are over 900 species and subspecies, about $30 \%$ of the flora of the entire Molise Region. Collemeluccio forest is a relict stand of the last post-glacial period, typical of the fir forests currently widespread in the Mediterranean and Anatolian regions, dominated by Abies alba Mill., mixed with Quercus cerris L., Fagus sylvatica L., Carpinus betulus L. and Ilex aquifolium L. Its structure and composition are similar to those of woodlands which were common in the past throughout the Apennines, but which nowadays survive only in small areas throughout the Italian peninsula (Santopuoli et al. 2016). Currently, silvicultural interventions are limited to naturalistic silviculture methods aimed at favouring the return of the forest to a natural state, and balance with local conditions, an equilibrium which is not easily or quickly achieved for this kind of forest. All these areas have become real field laboratories for research on forest ecosystems in the core area (e.g. silviculture and climate change adaptation, area of expansion of plant species and of rare or endangered animals, alien species monitoring, and conservation and improvement of natural grasslands). They are also the site of various programmes (ecotourism, environmental education, recreational activities). In 2003, for example, an educational programme created the Colle S. Biagio path in the Montedimezzo core area. Here, there are now facilities such as audio devices and electric wheelchairs, and an ecomuseum designed to be accessible by mobility- and visually-impaired visitors, one of the first examples in an Italian protected area; moreover, a wheelchairfriendly, level, surfaced path about $2 \mathrm{~km}$ long and $2 \mathrm{~m}$ wide has been created. Along the path, there are also educational panels in Braille with information on trees and environmental features. These educational and environmental facilities and elements of public awareness, which present the cultural heritage of the BR, are now being enhanced by environmental, traditional and cultural associations. One of these associations is involved in organizing weekly tours from Abruzzo to Molise, returning via the historic Carpinone-Sulmona railway. The trains stop at four stations in the BR and allow slow tourists to appreciate the rural landscape and villages affected by different social and economic issues, such as population ageing, outmigration and decreasing economic activities. According to the last population census (ISTAT 2020), the area is characterized by a depopulation rate of 28.5\% (from 1991 to 2020), with currently 4612 inhabitants and a population density of 18.2 inhabitants $/ \mathrm{km}^{2}$. The presence of a MAB Reserve could be an opportunity to boost the local economy and to promote awareness of the dynamic interrelationships between natural and nearnatural ecosystems, and the traditional practice there of transhumance (Ballacchino \& Bindi 2017; Figure 3). Adopting new socio-economic processes could 
Table 1 - Natura 2000 sites in the Collemeluccio-Montedimezzo Alto Molise Biosphere Reserve (SCI: Site of Community Interest; SPA: Special Protected Area).

\begin{tabular}{|c|c|c|c|c|c|}
\hline Municipality & $\begin{array}{l}\mathrm{SCl} / \mathrm{SPA} \\
\text { Code }\end{array}$ & \begin{tabular}{|l|}
$\mathrm{SCl}$ or \\
SPA
\end{tabular} & $\mathrm{SCl} / \mathrm{SPA}$ name & $\begin{array}{l}\text { Municipal area } \\
\text { (ha) within the } \\
\text { SCI/SPA }\end{array}$ & $\begin{array}{l}\text { Municipal area } \\
\text { within the SCI/ } \\
\text { SPA (\%) }\end{array}$ \\
\hline \multirow[t]{3}{*}{ Carovilli } & IT7212133 & $\mathrm{SCl}$ & Torrente Tirino (Forra) - Monte Ferrante & 138.54 & 3.33 \\
\hline & IT7212134 & $\mathrm{SCl}$ & Bosco di Collemeluccio - Selvapiana - Castiglione - La Cocozza & 662.80 & 15.95 \\
\hline & IT7221131 & SPA & Bosco di Collemeluccio & 0.71 & 0.02 \\
\hline \multirow{4}{*}{$\begin{array}{l}\text { Pescolan- } \\
\text { ciano }\end{array}$} & IT7221131 & SPA & Bosco di Collemeluccio & 467.81 & 13.47 \\
\hline & IT7212134 & $\mathrm{SCl}$ & Bosco di Collemeluccio - Selvapiana - Castiglione - La Cocozza & 1580.12 & 45.49 \\
\hline & IT7212125 & $\mathrm{SCl}$ & Pesche - MonteTotila & 266.22 & 7.66 \\
\hline & IT7212133 & $\mathrm{SCl}$ & Torrente Tirino (Forra) - Monte Ferrante & 6.73 & 0.19 \\
\hline \multirow[t]{2}{*}{$\begin{array}{l}\text { San Pietro } \\
\text { Avellana }\end{array}$} & IT7212124 & $\mathrm{SCl}$ & $\begin{array}{l}\text { Bosco Monte di Mezzo-Monte Miglio - PennataroMonte Capraro } \\
\text { - Monte Cavallerizzo }\end{array}$ & 1400.48 & 31.16 \\
\hline & IT7218213 & $\mathrm{SCl}$ & Isola della Fonte della Luna & 863.17 & 19.20 \\
\hline \multirow[t]{3}{*}{ Vastogirardi } & T7212124 & $\mathrm{SCl}$ & $\begin{array}{l}\text { Bosco Monte di Mezzo - Monte Miglio - PennataroMonte } \\
\text { Capraro - Monte Cavallerizzo }\end{array}$ & 1609.51 & 26.51 \\
\hline & IT7221132 & SPA & Monte di Mezzo & 313.28 & 5.16 \\
\hline & IT7212134 & $\mathrm{SCl}$ & Bosco di Collemeluccio - Selvapiana - Castiglione - La Cocozza & 397.90 & 6.55 \\
\hline
\end{tabular}

harmonize sustainable development issues with conservation, since the local population plays a key role in decision-making processes in management and planning (Van Cuong et al. 2017).

Community-based cooperatives, management of rural areas, and green tourism to counter depopulation

Population ageing, outmigration and a decreasing economy were recently addressed throughout Italy by the 2014 National Strategy for Inner Areas (Dipartimento per lo Sviluppo e la Coesione Economica 2014), in which significant socio-economic challenges were identified as drivers of land-use changes, particularly land abandonment and forest expansion. In order to act as a driving force for development, this national strategy to help inland areas whose vocation is to protect or to promote nature but which have shortcomings in services and development has been adopted in the Alto Molise area with the establishment of a Local Action Group consisting of 18 municipalities (GAL Alto Molise; Labianca et al. 2020). The funds they are now managing are aimed precisely at the development of agriculture (including livestock) and tourist activities within the BR, while safeguarding the natural environment. The implementation of development strategies relies both on horizontal and vertical co-planning processes, the former involving local communities, associations and institutions. The latter responds to the relationship between local and global demands (Barca et al. 2018), considers that the re-appropriation of abandoned land has a profound effect on local citizens, and promotes the social frame- work of rural landscapes (Atkociuniene et al. 2015). In this framework, the participation of local administrations is very important both for direct support (e.g. leases on public buildings for use by local groups), and for the purchase of goods and / or assignment of services (Bandini et al. 2015). In this mountainous area, recoverable uninhabited buildings could be devoted to tourist activities, in particular to comfortable dispersed hotels (alberghi diffusi) offering experiential, cultural tourism based on the classic themes of rural life (food and wine, landscape and the environment), as has already happened in the village of Castel del Giudice in Molise Region (Presenza et al. 2019). Moreover, the newly established, so-called community-based cooperatives could offer collective services (e.g. welfare, land care, management of urban green spaces) and carry out economic activities like mountain farming, tourism services, and craft enterprises. These communitybased cooperatives could take advantage of existing but unexploited or sleeping regional resources (Mastronardi \& Romagnoli 2020), such as forest biomass (in line with local forest management plans) through the creation of strategic partnerships, both inside and outside the community (Venturi \& Zandonai 2016). Moreover, the development of activities might require new expertise and, consequently, serve to enhance the educational level of local people, thus helping to limit the depopulation of the area. Municipalities could outsource to local cooperatives some services, such as land maintenance, urban green care, care of the elderly, school canteen management, and the promotion of environmental and heritage resources of tourist interest. Rural tourism could be a real development 


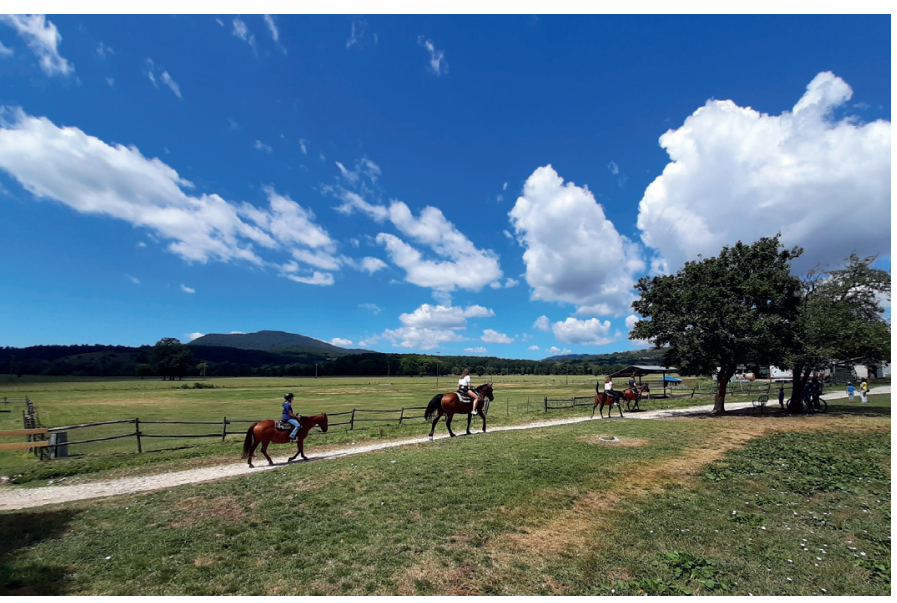

Figure 3-The Collemeluccio-Montedimezzo Alto Molise Biosphere Reserve (C) Sara Di Lonardo

factor for these inner areas (Lupi et al. 2017) since it satisfies people's need to enjoy nature, a feature which differentiates rural tourism from traditional tourism, and therefore requires suitable policies, which are currently being developed in Italy (Salvatore et al. 2018). Hence, the development of new forms of tourism in these inner areas could favour a proactive conservation of landscape (Salvatore 2015), arresting demographic decline, particularly the decay of working-age groups. A new community-based governance might promote the transition from a culture of emergency to a culture of prevention in the territory (Mastronardi et al. 2020) in order to achieve and support the three MAB Reserve aims - biodiversity, conservation and sustainable development - thereby, in the longer term, affecting landscape, environmental and cultural heritages for the better.

\section{Acknowledgements}

We are grateful to Dr. Mary Rigby for her valuable work in language editing.

\section{References}

Abbate, G. \& E. Giovi 2002. Flora vascolare della Riserva MaB "Collemeluccio-Montedimezzo" (Isernia, Italia meridionale). Webbia: Journal of Plant Taxonomy and Geography 57(1): 83-114.

Atkociuniene, V., G. Vaznoniene \& R. Pakeltiene 2015. Aim of the development of rural social infrastructure: a sustainable community. Transformations in Business \& Economics 14 (2A-35A): 42-59.

Ballacchino, K. \& L. Bindi 2017. Cammini di Uomini, Cammini di Animali. Transumanze, Pastoralismi e Patrimoni Bioculturali.

Bandini, F., R. Medei \& C. Travaglini 2015. Territorio e persone come risorse: le cooperative di comunità. Rivista Impresa Sociale 5: 19-35.

Barca, F., G. Carrosio \& S. Lucatelli 2018. Le aree interne da luogo di disuguaglianza a opportunità per il paese. In: Paolazzi, L., T. Gargiulo, \& M. Sylos Labini (eds.), Le sostenibili carte dell'Italia: 167-186.

Dipartimento per lo Sviluppo e la Coesione Economica 2014. Strategia nazionale per le Aree interne: definizione, obiettivi, strumenti e governance. Available at: https://www.miur.gov.it/documents/20182/890263/ strategia_nazionale_aree_interne.pdf/d10fc111-65c04acd-b253-63efae626b19 (accessed: 21/11/2020)

ISTAT 2020. Istituto Nazionale di Statistica, dati ufficiali sulla popolazione residente, al 01 gennaio 2020, nei Comuni italiani derivanti dalle indagini effettuate presso gli Uffici di Anagrafe. Available at: http://demo.istat.it/pop2020/ index.html (accessed: 21/11/2020)

Labianca, M., S. De Rubertis, A. Belliggiano, A. Salento \& F. Navarro 2020. Social Innovation, Territorial Capital and LEADER Experiences in Andalusia (Spain) and in Molise (Italy). In: Cejudo, E. \& F. Navarro (eds.), Neoendogenous Development in European Rural Areas: 111-131.

Lupi, C., V. Giaccio, L. Mastronardi, A. Giannelli \& A. Scardera 2017. Exploring the features of agritourism and its contribution to rural development in Italy. Land Use Policy 64: 383-390.

Mastronardi, L., M. Giagnacovo \& L. Romagnoli 2020. Bridging regional gaps: Community-based cooperatives as a tool for Italian inner areas resilience. Land Use Policy 99: 104979.

Mastronardi, L. \& L. Romagnoli 2020. Community-based cooperatives: a new business model for the development of Italian inner areas. Sustainability 12(5): 2082.

Presenza, A., A. Messeni Petruzzelli \& L. Sheehan 2019. Innovation through tradition in hospitality. The Italian case of Albergo Diffuso. Tourism Management 72: 192-201.

Salvatore, R. 2015. Between nature and landscape: the role of community towards an active conservation in protected areas. In: Gambino, R. \& A. Peano (eds.), Nature Policies and Landscape Policies: 223-231.

Salvatore, R., E. Chiodo \& A. Fantini 2018. Tourism transition in peripheral rural areas: theories, issues and strategies. Annals of Tourism Research 68: 41-51.

Santopuoli, G., B. Lasserre, P. Di Martino \& M. Marchetti 2016. Dynamics of the silver fir (Abies alba Mill.) natural regeneration in a mixed forest in the Central Apennine. Plant Biosystems 150: 217-226.

Van Cuong, C., P. Dart \& M. Hockings 2017. Biosphere reserves: attributes for success. Journal of Environmental Management 188: 9-17.

Venturi, P. \& F. Zandonai 2016. Imprese ibride. Modelli d'innovazione sociale per rigenerare valori. Cultura e società.

\section{Authors}

\section{Sara Di Lonardo}

is an environmental biologist with a $\mathrm{PhD}$ in Biosystematics and Plant Ecology, and is a researcher at the Research Institute on Terrestrial Ecosystems of the Italian National Research Council (IRET-CNR). She 
works on the dynamics and interactions among soil, organisms and the atmosphere. Since 2015, she has been working on citizen science and awareness-raising projects involving both children and adults, looking at environmental topics such as landscape and soil, and air management, quality and pollution.

Research Institute on Terrestrial Ecosystems - National Research Council (IRET-CNR), Via Madonna del Piano 10, 50019 Sesto Fiorentino (Fi), Italy. Email: sara.dilonardo@cnr.it

\section{Andrea Cinocca}

is an Environmental Engineer. He has a $\mathrm{PhD}$ in Mechanical Engineering, Energy and Management, and is a postdoctoral research fellow at the University of L'Aquila in Renewable Energy Sources, Energy
Audits and Local Energy Planning. He has drafted or coordinated the drafting of over 150 Sustainable Action Plans for Molise and Abruzzo Regions. He is currently a contract professor at the University of Teramo, Faculty of Veterinary Medicine - Sustainable Livestock Production Science, where he focuses on energy efficiency in breeding.

Department of Industrial and Information Engineering and Economics - University of L'Aquila, Via G. Gronchi 18, 67100 L'Aquila, Italy. E-mail: andrea. cinocca@univaq.it

Faculty of Veterinary Medicine - Sustainable Livestock Production Science - University of Teramo, Aurelio Saliceti Campus, Via R. Balzarini 1, 64100 Teramo, Italy. E-mail: acinocca@unite.it 